\title{
Preventing postpartum uterine disease in dairy cattle depends on avoiding, tolerating and resisting pathogenic bacteria
}

\author{
I Martin Sheldon $^{\mathrm{a}, *}$, Paula C C Molinari ${ }^{\mathrm{b}}$, Thomas J R Ormsby ${ }^{\mathrm{a}}$, John J Bromfield ${ }^{\mathrm{b}}$ \\ ${ }^{a}$ Institute of Life Science, Swansea University Medical School, Swansea University, Singleton \\ Park, Swansea, SA2 8PP, United Kingdom \\ ${ }^{b}$ Department of Animal Sciences, University of Florida, Gainesville, Florida 32611-0910, \\ United States of America \\ * Corresponding author. Professor Martin Sheldon, Swansea University Medical School, \\ Swansea University, Singleton Park, Swansea, SA2 8PP, United Kingdom.
}

Telephone: +44 1792602709 E-mail: IM Sheldon: i.m.sheldon@swansea.ac.uk

\begin{abstract}
Up to forty percent of dairy cows develop metritis or endometritis when pathogenic bacteria infect the uterus after parturition. However, resilient cows remain healthy even when exposed to the same pathogens. Here, we provide a perspective on the mechanisms that dairy cows use to prevent postpartum uterine disease. We suggest that resilient cows prevent the development of uterine disease using the three complementary defensive strategies of avoiding, tolerating and resisting infection with pathogenic bacteria. Avoidance maintains health by limiting the exposure to pathogens. Avoidance mechanisms include intrinsic behaviors to reduce the risk of infection by avoiding pathogens or infected animals, perhaps signaled by the fetid odor of uterine disease. Tolerance improves health by limiting the tissue damage caused by the pathogens. Tolerance mechanisms include neutralizing bacterial toxins, protecting cells against damage, enhancing tissue repair, and reprogramming metabolism. Resistance improves health by limiting the pathogen burden. Resistance mechanisms include inflammation driven by innate immunity and adaptive immunity, with the aim of killing and eliminating pathogenic bacteria. Farmers can also help cows prevent the development of postpartum uterine disease by avoiding trauma to the genital tract, reducing stress, and feeding animals appropriately during the transition period. Understanding the mechanisms of avoidance, tolerance and resistance to pathogens will inform strategies to generate resilient animals and prevent uterine disease.
\end{abstract}

Keywords: Bovine; Uterus; Metritis; Endometritis; Resilience

\section{Introduction}

Theriogenology published a set of definitions for postpartum uterine diseases in cattle in 2006 [1]. Since then, there has been increased understanding about the incidence, etiology, pathogenesis and consequences of the main postpartum uterine diseases - metritis and endometritis [2-7]. It is less clear why some dairy cows develop postpartum uterine disease when infected with pathogenic bacteria around the time of parturition, whilst other resilient 
cows remain healthy, even when exposed to the same pathogens. We suggest that resilient dairy cows prevent the development of uterine disease by avoiding, tolerating and resisting infection with pathogenic bacteria (Fig. 1).

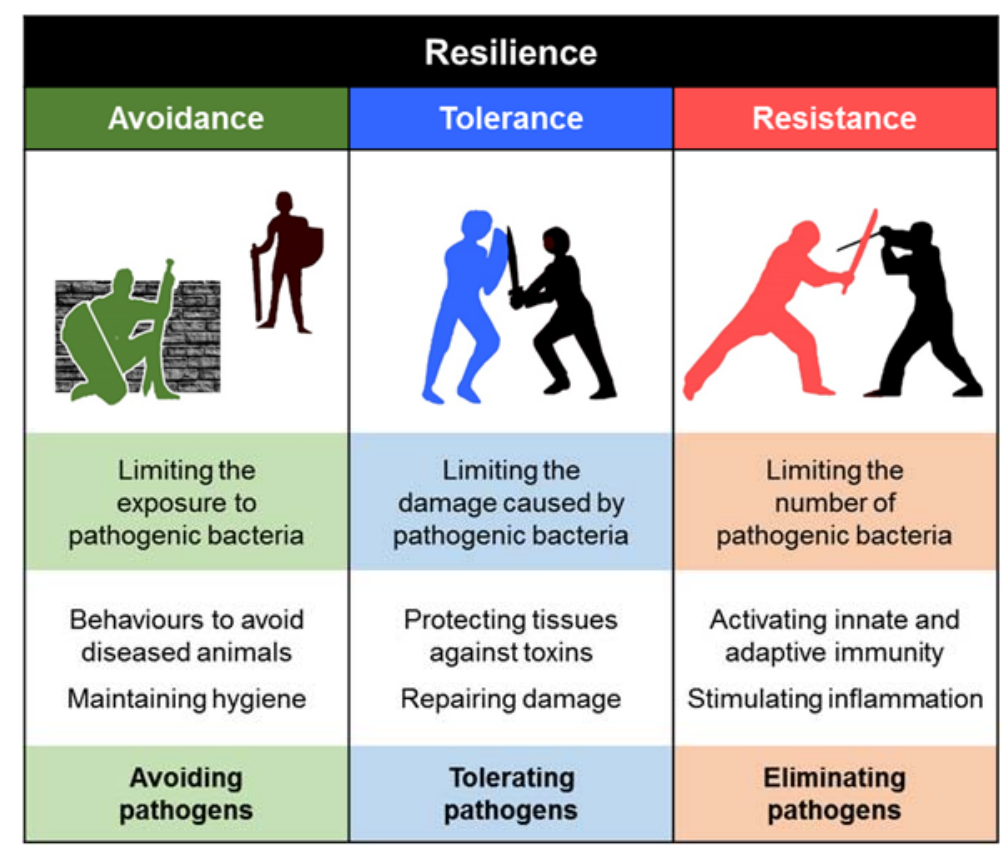

Figure 1. Resilient animals defend themselves against pathogens using the complementary defensive strategies of avoidance, tolerance and resistance. The cartoon sets out the concept for each strategy and provides examples of the mechanisms that animals use to defend themselves against pathogens.

The scientific framework for understanding defense against pathogens has developed over the last 120 years. The origins of the study of resistance - often equated with immunology - are often based on the work of Metchnikoff and Ehrlich, which led to their shared Nobel Prize in 1908 "in recognition of their work on immunity." Among several Nobel Prizes awarded in the field of immunology, the most recent was in 2011, for discoveries about innate immunity and dendritic cells. The importance of tolerance was first recognized in plants, which have evolved mechanisms to counter the damage caused by pathogens and herbivores [8]. More recently, tolerance mechanisms were identified in animals and the role of tolerance in countering pathogens is an emerging area of animal research [9-12]. The role of avoidance behaviors in countering pathogens is also a relatively new field of research, with the recognition of pathogen-mediated avoidance behaviors in the last 25 years [13, 14]. Here we have adapted and applied the three defensive strategies of avoidance, tolerance and resistance, to help understanding of the prevention of postpartum uterine disease in cattle.

Avoidance is the ability to limit the exposure to pathogens [14]. Typically, this involves animals using intrinsic behaviors to avoid pathogens and reduce the risk of infection. Tolerance is the ability to limit the tissue damage caused by the pathogen burden [9]. Tolerance mechanisms include neutralizing bacterial toxins, protecting cells against damage, enhancing tissue repair, and inducing adaptive metabolic responses. Resistance is the ability to limit the 
pathogen burden $[10,12]$. Resistance is the function of immunity, which aims to kill and remove pathogen. Resilience is the aggregate of the complementary defensive strategies of avoidance, tolerance and resistance. Resilient animals prevent disease or restrict the severity of disease $[7,10,12]$. We assume that the evolutionary ancestors of cattle were resilient to postpartum uterine infections, but it is now common to read reports that twenty to forty per cent of modern dairy cows develop some form of postpartum uterine disease [2, 15-20].

We treat animals with uterine disease because the disease causes pain, reduces milk yields, and reduces fertility [21, 22]. However, the current use of antibiotics to treat uterine disease needs rethinking because, although antibiotics help resolve the clinical signs, there is still reduced fertility [23]. Furthermore, the use of antimicrobials in food-producing animals is increasing discouraged by governments that are concerned about the spread of antimicrobial resistance [24]. The annual cost of the reduced fertility, lost milk production, and treatment of metritis was estimated to be $€ 1.4$ billion in the European Union and $\$ 650$ million in the USA [2]; a case of metritis costs farmers up to $\$ 410$ in the USA [25]. Prevention of postpartum uterine disease would be better than cure, for both the animals and the economy.

Here we outline the role of bacteria in postpartum uterine disease and provide a perspective on the mechanisms that dairy cows use to prevent postpartum uterine disease. We encourage readers to consult comprehensive reviews if they require information on pathogens other than bacteria, or more detail about the pathogenesis, diagnosis and treatment of uterine disease [27]. Instead, we aim to bring new ideas to light and challenge readers to think about how resilient dairy cows prevent postpartum uterine disease. In particular, we focus on how preventing postpartum uterine disease depends on avoiding, tolerating and resisting infections with pathogenic bacteria.

\section{The postpartum period}

Optimal fertility in dairy cows depends on completing several integrated physiological processes in the first five weeks after parturition: prompt involution of the uterus and restoration of a receptive endometrium; resumption of ovarian cyclical activity and ovulation of competent oocytes; and, control of pathogenic bacteria in the uterus. Uterine involution involves reparative inflammation, remodeling the extracellular matrix, and regenerating the epithelium [26, 27]. There is concurrent return of ovarian cyclic activity, driven by coordinated endocrine programs in the hypothalamus, pituitary, ovary, and uterus [28-30]. The high concentrations of steroid hormones during pregnancy decrease to basal values within days of parturition. Plasma follicle stimulating hormone concentrations increase about 7 days after parturition, which prompts the emergence of a cohort of growing follicles in the ovary, with subsequent waves of growing follicles every 7 to 10 days. In normal animals, the first postpartum dominant follicle should ovulate, indicating the return of ovarian cyclic activity. However, disease or inadequate nutrition during the transition period ( 3 weeks before to 3 weeks after parturition) delays uterine involution and the return of ovarian cyclic activity [28, $31,32]$. 
We propose that animals control (tolerate) rather than eliminate (resist) pathogenic bacteria in the postpartum uterus because healthy animals have an endometrial microbiota - a community of commensal, symbiotic and pathogenic microorganisms [33-35]. For example, uterine pathogens such as Trueperella pyogenes, Fusobacteria species and Prevotella species have been identified in the uterus of healthy cattle, even during pregnancy [33, 34]. However, these data require caution after a study of 537 women found that despite the expectation there would be a microbiota, the placenta and amnion did not usually contain bacteria [36]; most of the nucleotide signals for bacteria were from contamination of samples or laboratory reagents. Irrespective of whether there is a microbiota in the bovine uterus during pregnancy, the microbial community blooms after parturition. The bacterial load expands massively and fluctuates widely, presumably because vaginal and cervical dilation and trauma allow contamination of the genital tract with bacteria from the vagina, skin, blood, feces and environment.

The pathogenic bacteria cultured from animals with uterine disease include Escherichia coli, T. pyogenes, Fusobacterium necrophorum, and Prevotella and Bacteroides species [37]. Genomic techniques have identified additional bacterial phyla that are more abundant in the uterus of animals with metritis compared with the healthy uterus, including Bacteroidetes, Fusobacteria, Lactococcus, Proteobacteria and Firmicutes [35, 38, 39]. However, prior to the development of disease there is evidence that many of the bacteria are common amongst animals that will or will not develop metritis. Using high-throughput metagenomic sequencing of the 16S rRNA gene on the Illumina MiSeq platform it was reported that, although the microbiota changed in uterine samples from the day of parturition to 6 days postpartum, cows that would subsequently develop metritis or maintain a healthy uterus had a similar uterine microbiota on the day of parturition [40]. The proportion of core bacterial genera shared between cows developing metritis and healthy cows was $77 \%$ at parturition, $79 \%$ by 2 days postpartum, and $60 \%$ by 6 days postpartum. Similar experimental approaches also independently reported that cows that remain healthy and cows that develop metritis share bacterial phyla and genera in postpartum uterine samples [41, 42]. Furthermore, apart from Bateroides, there was no significant difference in the abundance of the 15 most frequent bacterial genera in the uterus of healthy and metritis cows 0,2 or 6 days postpartum [43]. As many pathogens infect both healthy and diseased uteri, it is unclear whether specific keystone bacteria, combinations of bacteria, failures in tolerance, or an increased abundance of bacteria causes uterine disease. For example, in the first weeks after parturition, strains of endometrial pathogenic E. coli are found in cows with uterine disease [44, 45]. Beyond three weeks after parturition, Trueperella pyogenes is the pathogen most correlated with the severity of endometritis and extent of the infertility [46-48].

\section{Uterine disease}

The clinical definitions of postpartum uterine disease are well established $[1,7,49,50]$. Metritis commonly occurs within 10 days of parturition, and cows have an enlarged uterus, containing watery red-brown fluid to viscous off-white pus, which has a fetid odor. The severity of disease ranges from inapparent signs of metritis to pyrexia and inappetence in 
animals with puerperal metritis, and even toxemia and shock in some animals. Clinical endometritis is characterized by the presence of pus in the uterus 21 days or more after parturition, usually with a purulent uterine discharge detectable in the vagina. Subclinical endometritis is diagnosed when there are no signs of clinical endometritis but the proportion of neutrophils in endometrial flush or cytobrush samples exceeds thresholds associated with reduced reproductive performance, which is usually about $5 \%$ of cells. New knowledge is required to understand how the etiology and pathogenesis of endometritis differs from purulent vaginal discharge caused by cervicitis or vaginitis [19]. Future longitudinal studies should examine the temporal interrelationships amongst the pathogens, and the progression of disease in the reproductive tract.

The lactational incidence of metritis was $21 \%$ in a survey of farm records of 97,318 Holstein cows in the USA [16]; although the farmers included retained fetal membranes when recording metritis, this incidence is the same as the $21 \%$ lactational incidence of metritis in 456 animals in Florida that were examined daily after parturition [51]. The lactational incidence of endometritis was $19 \%$ in a survey of farm records for 19,870 Holstein cows in Germany [17]; again, similar to the $17 \%$ lactational incidence of clinical endometritis in 1,865 cows in Canada examined in detail 20 to 33 days postpartum [52]. Metritis is also important in purebred Bos indicus cows, crossbred Bos indicus x dairy cows, and buffalo. For example, in 1,609 Sahiwal lactations, 2,549 crossbred Holstein x Tharparkar lactations, and 1,604 Murrah buffalo lactations, the incidence of metritis was $10.3 \%, 22.6 \%$, and $9.7 \%$, respectively [53]. Uterine disease is important because it causes infertility or reduces fertility, even after successful treatment of the disease. Even though farm records can have imprecise case definitions, in a meta-analysis of more than 10,000 cases, metritis increased the time to first insemination by 7.2 days, reduced conception rates to first insemination by $20 \%$, and increased the calving-toconception interval by 18.6 days [22]. These data are similar to a precise case-controlled study of 1,865 cows in Canada, where clinical endometritis increased the time to first insemination by 5 days, reduced conception rates to first insemination by $8 \%$, increased the median days open by 28 days, and cows were 1.7 times more likely to be culled for reproductive failure than cows without endometritis [52]. The reduced fertility is caused by inflammation of the genital tract, disruption of ovarian follicle growth and function, abnormal estrous cycles, and damage to oocytes $[4,15,20,37,54,55]$. To avoid reduced fertility, we argue that prevention of disease is more important than developing new treatments for metritis or endometritis.

\section{Defense against pathogens in the uterus}

Uterine disease provides an opportunity to study animal resilience because, despite exposure of the uterus to similar bacteria, the incidence of disease varies amongst groups of animals, levels of milk production, breeds, and farms. We suggest that preventing uterine disease depends on the complementary defensive strategies of avoidance, tolerance and resistance. These are evolutionary ancient strategies used by plants and animals to counter infection or damage $[8,10,12]$. Avoidance, tolerance and resistance are integrated and complementary strategies, but they have different implications for the interaction between pathogen burden and health. This interaction between pathogen burden and health can be visualized using a reaction 
norm plot (Fig. 2). Reaction norms for a population of animals also allow comparisons between different genotypes, breeds or environments [8, 10, 12, 56-58]. For example, dairy cows in straw yards are more able to avoid fecal pathogens than cows in cubicles [59]; dairy cows with lower milk yields are more able to tolerate uterine pathogens [7]; and, cows with higher cell mediated immune response are more able to resist uterine pathogens causing metritis [60].

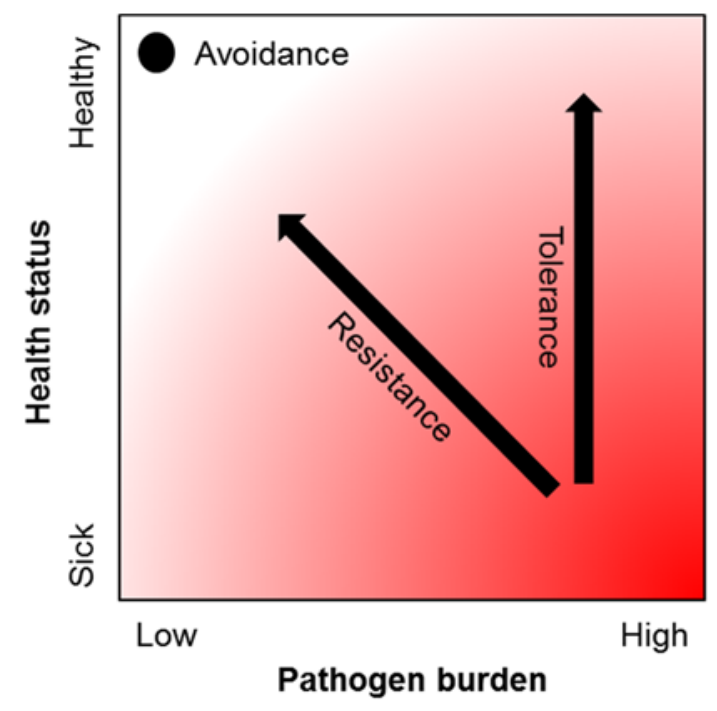

Figure 2. Reaction norms: a conceptual framework for understanding resilience to pathogens. A theoretical reaction norm plot of health status, where health increases vertically, against pathogen burden, where the pathogen burden increases horizontally [7, 10, 12]. Avoidance maintains health by avoiding exposure to pathogens. Tolerance improves health by limiting the tissue damage caused by the pathogen burden. Resistance improves health by limiting the pathogen burden. In the case of uterine disease, avoidance limits the quantity of pathogens reaching the uterus, tolerance limits the damage that pathogens infecting the uterus cause to the endometrium, and resistance reduces the quantity of pathogens that infect the uterus.

\subsection{Avoidance}

Avoidance mechanisms that limit exposure to pathogens have an evolutionary advantage over tolerance and resistance mechanisms because there is no direct metabolic cost to the animal of countering the pathogens. Furthermore, basal metabolism fuels the indirect metabolic costs of avoidance mechanisms such as barriers and behavior. Examples of physical barriers to infection that help avoid bacteria ascending the genital tract into the uterus are the vulva, vagina, cervix, and cervical mucus. However, calving, dystocia, and poor conformation of the vulva or vagina, breach these physical barriers and allow bacteria to invade the uterus.

Maintaining hygiene is an intrinsic behavior that has evolved over millennia in most species of animals [61]. The preference of animals to avoid feces, clean themselves, and prefer dry and clean bedding is such an intrinsic behavior that it often goes unremarked. For example, selfgrooming and grooming each other is an intrinsic behavior used by many species to maintain hygiene, remove parasites, and for social interaction. Similarly, cows use grooming to maintain coat hygiene and limit stress $[62,63]$. 
A greater understanding is needed about whether cows use intrinsic behaviors to avoid uterine pathogens. However, cows seek seclusion from herd-mates around the time of parturition, and cows with metritis display sickness behaviors, including inappetence, inactivity, isolation, and depression, which result in sick cows spending more time away from healthy herd-mates [64]. Other intrinsic behaviors to avoid pathogens, which have been studied in non-ruminants, are keeping away from other animals of the same species because they are most likely to harbor pathogens, and using disgust to avoid the odor of pathogens or infection [13]. For example, the nematode Caenorhabditis elegans, which feeds on bacteria, learns to avoid the odor of pathogenic bacteria, whilst being attracted to odors from nonpathogenic bacteria [65]. Bullfrog tadpoles avoid other tadpoles that are infected with a pathogenic yeast by detecting chemical signals from infected individuals [14]. Mice use the vomeronasal system to detect the odor of animals that have an infection or even an inflammatory response to the bacterial endotoxin lipopolysaccharide [66]. In the case of postpartum metritis, the fetid odor is disgusting to humans. Although cows use averse odors to avoid feces [59], it remains to be determined whether herd-mates use the fetid odor to avoid cows with metritis.

The value of avoidance behaviors for postpartum uterine disease depends on how transmissible uterine pathogens are, and how easily these pathogens spread when there is a high density of animals. Confined dairy cows often have a higher incidence of postpartum uterine disease than herds of free-ranging beef cattle or wild ungulates. There is an urgent need to better understand the behavior of postpartum cows because modern dairy production systems and buildings are likely to compromise the ability of postpartum animals to use avoidance behaviors [67]. If they are important, allowing cows to use behaviors that avoid infections may require a revaluation of current housing design and transition cow management.

\subsection{Tolerance}

Tolerance - not to be confused with immunological tolerance - aims to benefit an animal's health by limiting the tissue damage pathogens cause without affecting the pathogen burden $[7,10,12]$. An advantage of tolerance over resistance mechanisms is that tolerance does not exert a selection pressure on the pathogens that would provoke the pathogen to develop countermeasures, such as antimicrobial resistance. Tolerance mechanisms against uterine pathogens include functional barriers to bacterial infection, neutralization of bacterial toxins, repair of tissue damage, and adaptive metabolic responses (Table 1). For example, the epithelial barrier of the endometrium and the overlying mucus layer facilitate the coexistence of pathogens and host. However, these tolerance mechanisms are not always passive and some integrate with resistance. Mucus from the reproductive tract contains antimicrobial peptides, acute phase proteins, such as haptoglobin and serum amyloid A, and mucosal glycoproteins that neutralize bacteria or their toxins [68-70]. Furthermore, there is increased expression of antimicrobial peptides and acute phase proteins in the inflamed endometrium and the peripheral plasma of postpartum cows $[71,72]$. 
Table 1. Potential disease tolerance mechanisms

\begin{tabular}{|c|c|}
\hline Mechanism & Examples \\
\hline \multirow{2}{*}{$\begin{array}{l}\text { Functional barriers to } \\
\text { infection }\end{array}$} & Mucus \\
\hline & Epithelium \\
\hline \multirow{2}{*}{$\begin{array}{l}\text { Neutralization } \\
\text { bacterial toxins }\end{array}$} & Antimicrobial peptides \\
\hline & Acute phase proteins \\
\hline \multirow{3}{*}{$\begin{array}{l}\text { Repair of tissue } \\
\text { damage }\end{array}$} & $\begin{array}{l}\text { Cell membrane repair in response to damage caused by bacterial } \\
\text { virulence factors, such as pore-forming toxins }\end{array}$ \\
\hline & DNA repair in response to DNA damage caused by endotoxin \\
\hline & $\begin{array}{l}\text { Unfolded protein response to intracellular proteins damaged by } \\
\text { bacteria }\end{array}$ \\
\hline \multirow{4}{*}{$\begin{array}{l}\text { Adaptive } \\
\text { responses }\end{array}$} & $\begin{array}{l}\text { Autophagy in response to damage to cellular organelles by } \\
\text { intracellular pathogens or changes in cell metabolism }\end{array}$ \\
\hline & $\begin{array}{l}\text { Hypoxia responses to the reduced oxygen availability in damaged } \\
\text { tissues }\end{array}$ \\
\hline & Oxidative stress responses to hemolysis or inflammation \\
\hline & $\begin{array}{l}\text { Reprogramming cell metabolism, such as using aerobic glycolysis to } \\
\text { generate substrates and energy for tissue repair }\end{array}$ \\
\hline
\end{tabular}

Damage control and tissue repair help tolerate the presence of pathogens [56, 73]. However, damage, repair and regeneration of the endometrium is also a consequence of parturition [26, 27]. The importance of the epithelial barrier for tolerating pathogens in the uterus is highlighted by the need to damage the epithelium when generating animal models of endometritis [74]. Crucially, loss of the epithelium allows pathogens to reach the underlying sensitive stroma in postpartum animals or when inducing disease. For example, stromal cells are ten times more sensitive than epithelial cells to damage by the pore-forming toxin pyolysin, which is the cholesterol-dependent cytolysin secreted by $T$. pyogenes [75]. However, it is possible, without impairing the intrinsic viability of stromal cells, to protect stromal cells against the damage caused by pyolysin in vitro, by reducing their cellular cholesterol content using methyl- $\beta$ cyclodextrin (Fig. 3), or by inhibiting cholesterol biosynthesis using statins or squalene synthase inhibitors [75-78]. These findings could lead to products that protect the endometrium against pathogen damage.

Damage and pore-forming toxins also prompt cell stress responses: activating the mitogenactivated protein kinases, activating the unfolded protein response, activating caspase enzymes, suppressing protein synthesis, and inducing autophagy [76, 79]. These cell stress responses aim to help repair damaged membranes and organelles, and to induce a quiescent state [58]. 
Sickness behaviors, such as inappetence, also activate catabolic pathways that induce cell quiescence and support tolerance to pathogens in humans and mice [58]. However, dairy cows often struggle to meet the metabolic requirements of lactation (the metabolisable energy required to produce 40 liters of milk is $200 \mathrm{MJ} / \mathrm{d}$; three times the energy needed for resting metabolism), and higher milk yields are associated with reduced tolerance to postpartum uterine infections [7]

A

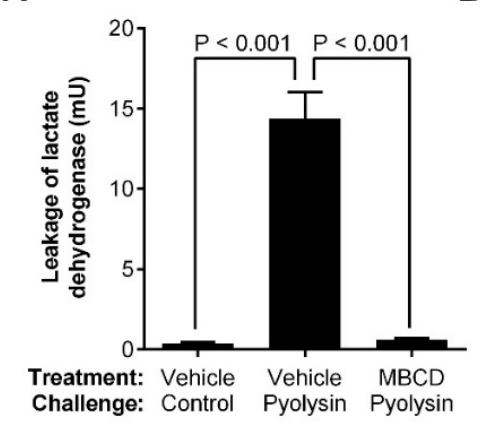

B

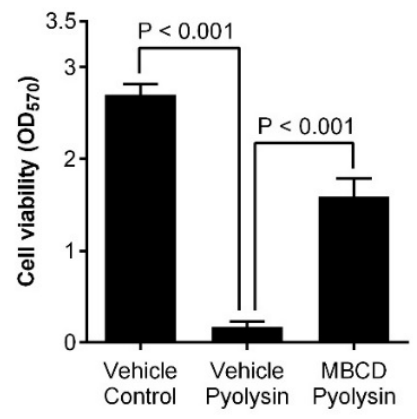

Figure 3. Reducing cellular cholesterol protects stromal cells against pyolysin. Bovine endometrial stromal cells were treated for $24 \mathrm{~h}$ in medium containing vehicle or methyl- $\beta$ cyclodextrin (MBCD) to deplete cellular cholesterol, and then challenged for $2 \mathrm{~h}$ with control medium or medium containing the cholesterol-dependent cytolysin, pyolysin. The formation of cell membrane pores was determined by the leakage of lactate dehydrogenase (A) and cell viability was examined using a colorimetric assay for mitochondrial activity (B). Data are presented as mean + SEM ( $\mathrm{n}=4$ animals), and analyzed by ANOVA with Bonferroni post hoc tests. Redrawn from data published previously [77].

\subsection{Resistance}

Whilst the research fields of avoidance and tolerance are still developing, there is extensive knowledge about resistance mechanisms against pathogens, and particularly the roles of innate and adaptive immunity. The innate immune system generates an immediate, non-specific response to pathogens that does not depend on prior exposure to pathogens [57, 80]. This innate immune response is ideal for uterine infections because they are polymicrobial and fluctuate during the postpartum period. Innate immune cells use pattern recognition receptors, such as Toll-like receptors, to recognize pathogen-associated molecular patterns, including bacterial DNA, lipopeptides, flagellin and lipopolysaccharide (endotoxin). In the uterus, endometrial epithelial and stromal cells also have a role in innate immunity, generating inflammatory responses to bacteria, lipopeptides, and lipopolysaccharide [81, 82]. The immune response typically results in the secretion of antimicrobial peptides, cytokines such as interleukin (IL)$1 \beta$ and IL-6, chemokines such as IL-8, and prostaglandin E2 [80, 83]. These inflammatory mediators help counter bacteria in the tissue by inducing vasodilation, attracting and activating immune cells, and inducing the production of acute phase proteins and reactive oxygen species $[7,80,83,84]$. The inflammatory mediators also suppress the hypothalamic-pituitary-ovary axis, and induce sickness behaviors, such as inappetence and lethargy [58]. The complement 
system, which promotes phagocytosis of pathogens by neutrophils and macrophages, provides additional non-specific defense [32].

A general concept is that rapid and robust inflammatory responses efficiently control pathogens, whereas delayed or blunted inflammatory responses lead to persistent inflammation $[7,57,58,80,83]$. Interestingly, intrauterine infusion of IL-8 recombinant protein reduced the incidence of clinical metritis from $34 \%$ to less than $10 \%$ [18]. However, excessive or unrestrained inflammation causes immunopathology, such as toxemia and shock in some cases of metritis. Conversely, subclinical endometritis is an example of persistent or unresolved inflammation. Fortunately, innate immunity usually regulates the inflammatory response to match the level of pathogen challenge and tissue damage. For example, feedback loops, such as STAT3 (signal transducer and activator of transcription-3), regulates the IL-6 and IL-8 response to lipopolysaccharide in endometrial cells [85]. Tissue damage, with the release of damage-associated molecular patterns also scales the immune response [86]. Damaged endometrial cells release the intracellular cytokine IL-1 $\alpha$, which stimulates further secretion of IL-6 [84]. Innate immunity also integrates with tolerance because the innate immune response induces the production of mucins and antimicrobial peptides [87].

Adaptive immunity depends on prior exposure to specific antigens and takes longer to develop than innate immunity. Adaptive immunity is evident in the postpartum endometrium, with lymphocytic foci of T cells and B cells [27, 47]. Furthermore, postpartum uterine disease is less likely if cows have increased levels of circulating antibodies, and vaccines containing components of E. coli, F. necrophorum and/or T. pyogenes can protect against metritis [88]. Unfortunately, domestication and selective breeding have reduced the diversity of major histocompatibility complex antigens, and retained fetal membranes are more common in animals with reduced major histocompatibility complex antigen diversity [89]. Another concern is that adaptive immunity is short-lived in the uterus. Spontaneous metritis does not protect against uterine disease after the next calving.

Unfortunately, the biosynthetic demand to repair the endometrium after parturition and resist pathogens is at odds with the additional metabolic demands of lactation [3]. For example, cows in severe negative energy balance after parturition have persistent endometritis, whereas animals with mild negative energy balance repair their endometrium by two weeks after parturition [32]. Even reduced feeding behavior before parturition predicts the development of metritis [90]. A widely accepted mechanism is that metabolic changes around the time of parturition impair neutrophil function [3, 91]. Furthermore, deficiencies in glucose or glutamine also blunt the inflammatory response in the endometrium [92, 93]. Perhaps this interaction between metabolism and immunity is not surprising. It is energetically expensive to mount an immune response, secrete inflammatory mediators, and repair tissue damage, and this often results in negative energy balance and negative nitrogen balance [94]. Not only do immune cells require metabolites, the immune response also reprograms cellular metabolism to deliver the immune response [58, 95]. Estimated energetic costs of an immune response range from a $15 \%$ to $30 \%$ increase in resting metabolic rate [94]. An example of the energetic cost of innate immunity in the whole animal is that cows metabolize an extra kilogram of blood 
glucose in the first 12 hours after challenge with lipopolysaccharide [96]. Allocating additional metabolic resources to resistance during an infection requires trade-offs with other metabolically demanding processes that are not essential, which in many species is exemplified by reduced reproduction $[58,94]$. The negative energy balance of lactation is one such tradeoff in dairy cows, often made worse by an inadequate food supply or by sickness behaviors that reduce feeding. In an extreme example, challenging bees with lipopolysaccharide when they are starved increases mortality by 1.5 fold [97]. Despite evidence that negative energy balance is a risk factor for developing disease, and the metabolic cost of resisting pathogens, it is not clear how diets should be formulated for cows to optimize their immunity during the transition period [31].

\section{Managing cows to prevent uterine disease}

Whilst resilience to uterine infection depends on an animals' avoidance, tolerance and resistance strategies, good management can also help support animal resilience (Fig. 4). Uterine disease is not inevitable; many well-managed dairy farms have high milk yields but a low incidence of postpartum uterine disease. Conversely, and perhaps more important for animal welfare, suboptimal management of dairy cows can make cows more susceptible to postpartum uterine disease.

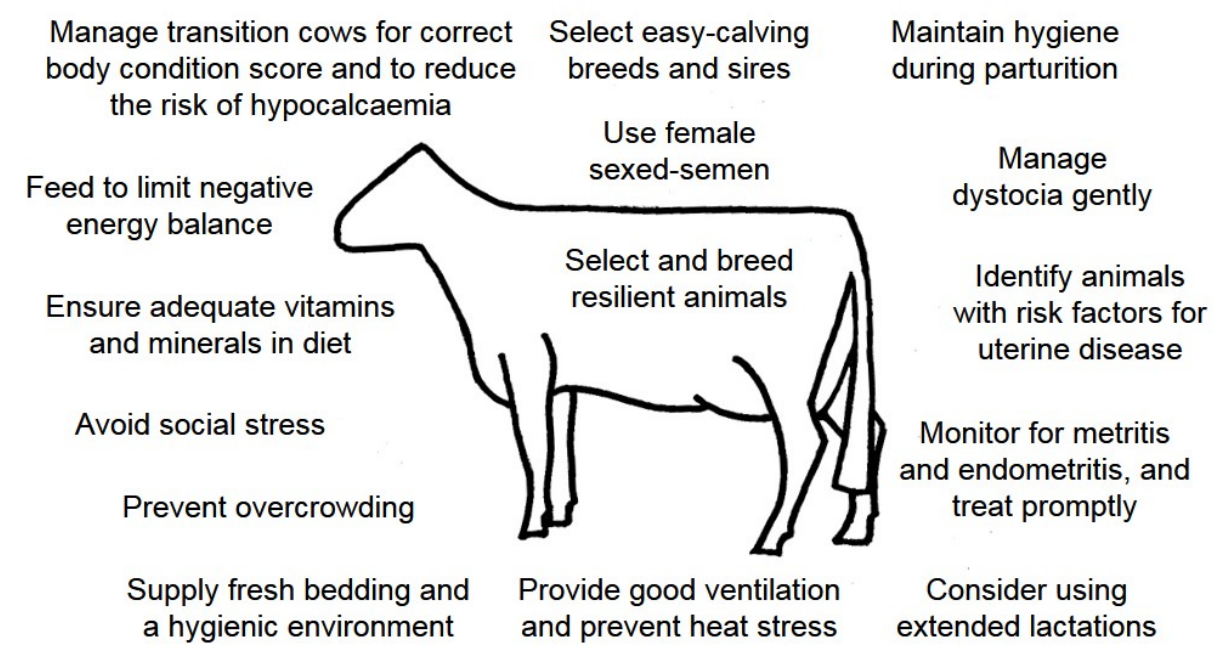

Figure 4. Management can help prevent postpartum uterine disease. Potential strategies that farmers can use to help prevent postpartum uterine disease.

An obvious way to avoid postpartum uterine disease is to avoid parturition. Farmers already use extended lactations as a management tool to reduce the frequency of parturition in Bos taurus dairy cows, which reduces the annual incidence of postpartum problems. Whilst extended lactations are often thought to reduce herd reproductive performance, in some cases extended lactations improve performance [98]. Unfortunately, extended lactations are impractical in seasonally calved herds, and for Bos indicus and crossbred dairy cows that have less persistent lactation than Bos taurus cows. Pharmaceutical induction of lactation with estrogens and progesterone also avoids parturition, but the protocols need further development 
to reduce the number of injections administered to each cow, and many countries prohibit the use of estrogens in food-producing animals.

Farmers can also try to control the risk factors for uterine disease. The predominant risk factors for postpartum uterine disease are trauma to the genital tract followed by colonization with pathogenic bacteria. Trauma to the genital tract is more likely in the first parity, after induction of parturition, or following dystocia, stillbirths, twins, male calves, or retained placenta [99101]. Selection of easy-calving breeds and easy-calving sires within a breed could reduce the risk of parturient trauma to the genital tract, but may produce only short-term benefits if the smaller offspring are then used as replacement dairy cows. Using sexed semen to produce female calves, which are smaller than male calves, is a practical way of reducing the risk of uterine disease; mathematical modelling of the replacement of male calves by female calves estimates that this strategy would prevent more cases of clinical endometritis in a herd than eliminating an infrequent risk factor, such as retained fetal membranes [101]. Cows should have a clean, comfortable, quiet, and spacious environment to calve without stress. If there is need for intervention during parturition, farmers and veterinarians should ensure that they use clean techniques, they are gentle, and they maintain the cleanliness of the environment.

Prevention of uterine disease also requires appropriate nutritional management during the transition period $[3,31]$. Cows should be dried off at the target body condition score, fed a prepartum cow diet that provides the appropriate fiber, vitamins and minerals, and then feed a postpartum diet with sufficient energy and protein to satisfy the metabolic requirements for lactation [102]. Farmers should also minimize stress, for example by avoiding transport or multiple changes in animal groups, which lead to social stress [103]. After parturition, it is important to monitor animal health carefully, particularly those cows that experience risks factors for uterine disease. Veterinary examination of the reproductive tract is important to identify animals with disease and decide on their treatment [6]. However, the routine use of antimicrobials in cows after parturition to try to prevent uterine disease is no longer acceptable because this metaphylaxis increases the risk of antimicrobial resistance, and reducing antimicrobial resistance is a priority for most human health agencies [24].

Encouraging a return to ovarian cyclic activity by appropriate nutrition and reproductive management during the transition period also helps counter uterine disease. Estrus and estradiol increase protection against uterine disease in cattle, and the induction of estrus is often used to treat endometritis [104]. Conversely, progesterone is used to suppress immunity when generating animal models of endometritis [74]. Interestingly, estrus and estradiol increase the expression of components of the complement system [105], but estrus and estradiol do not alter the innate immune response by endometrial tissues or cells in ex vivo studies [106]. It remains an open question as to how steroids influence the susceptibility of animals to uterine disease.

\section{Future perspectives}

In the present review, we suggest that resilient cows prevent the development of uterine disease using the three complementary defensive strategies of avoiding, tolerating and resisting infection with pathogenic bacteria. Preventing endemic diseases is important for delivering 
sustainable intensification of dairy farming, which will be necessary to feed the projected world population of 9.4 billion people by 2050 [107]. Improving resistance, particularly by developing vaccines probiotics or biopharmaceuticals holds promise [18, 88]. Unfortunately, this does not overcome the problem that high-milk-yield dairy cows are intrinsically more prone to develop uterine disease than other cattle or domesticated species. Farmers should also be aware that suboptimal management of dairy cows increases the risk of uterine disease. The simplest piece of advice is for farmers, nutritionists, and veterinarians to pay attention to detail when designing buildings, managing dairy herds, planning and herd health programs.

A long-term solution to preventing uterine disease is to breed resilient dairy cows that not only have a robust immune system, but also tolerate uterine pathogens [108]. Phenotypic selection could be based on the occurrence and severity of clinical disease but this is subjective, and the time required to collect the data results in long generation intervals. Genomic selection for resilient animals has high potential but depends on identifying genomic markers of animal resilience, rather than just focusing on genes that determine resistance [108]. However, genomic selection requires care because there can be a negative correlation between resistance and tolerance genes $[10,12]$. Improving avoidance or tolerance is another highly attractive strategy for preventing disease because, unlike resistance or using antimicrobials, avoidance and tolerance do not exert a selection pressure on the microbes. Improving avoidance or tolerance would also reduce the dependence on antimicrobials to kill pathogens, which helps reduce the danger to human health posed by antimicrobial resistance [24]. We propose that developing new ways to prevent uterine disease will depend on improving our understanding of the mechanisms of avoidance and tolerance of pathogens, to complement our knowledge about resistance in the postpartum uterus.

\section{Acknowledgements}

We thank Sian Owens, James Cronin, John Harwood, Stephen LeBlanc, Robert Gilbert, Tom Wilkinson, Pierre Comizzoli, and Jose Santos for informative discussions. We thank Joao Saut, Nicola Bettiol, Nick Bell and the reviewers for helpful comments on the manuscript. Work in the authors' laboratories is supported by the Eunice Kennedy Shriver National Institute of Child Health and Human Development of the National Institutes of Health (R01HD084316). The funding agency did not have any role in writing the article.

\section{Declarations of interest}

Declarations of interest: none.

\section{Author contributions}

Martin Sheldon: conceptualization, writing - original draft, funding acquisition; Paula Molinari: writing - review and editing; Tom Ormsby: writing - review and editing; John Bromfield: conceptualization, writing - review and editing, funding acquisition. 


\section{References}

[1] Sheldon IM, Lewis GS, LeBlanc S, Gilbert RO. Defining postpartum uterine disease in cattle. Theriogenology 2006;65:1516-30.

[2] Sheldon IM, Cronin J, Goetze L, Donofrio G, Schuberth HJ. Defining postpartum uterine disease and the mechanisms of infection and immunity in the female reproductive tract in cattle. Biol Reprod 2009;81:1025-32.

[3] LeBlanc SJ. Interactions of metabolism, inflammation, and reproductive tract health in the postpartum period in dairy cattle. Reprod Domest Anim 2012;47 Suppl 5:18-30.

[4] Bromfield JJ, Santos JE, Block J, Williams RS, Sheldon IM. Physiology and endocrinology symposium: Uterine infection: Linking infection and innate immunity with infertility in the high-producing dairy cow. J Anim Sci 2015;93:2021-33.

[5] Gilbert RO. Symposium review: Mechanisms of disruption of fertility by infectious diseases of the reproductive tract. J Dairy Sci 2019;102:3754-65.

[6] Sheldon IM. 23 - the metritis complex in cattle. In: Noakes DE, Parkinson TJ, England GCW, editors. Veterinary reproduction and obstetrics (tenth edition). St. Louis (MO): W.B. Saunders; 2019. p. 408-33.

[7] Sheldon IM, Cronin JC, Bromfield JJ. Tolerance and innate immunity shape the development of postpartum uterine disease and the impact of endometritis in dairy dattle. Annual Review of Animal Biosciences 2019;7:361-84.

[8] Rausher MD. Co-evolution and plant resistance to natural enemies. Nature 2001;411:85764.

[9] Raberg L, Sim D, Read AF. Disentangling genetic variation for resistance and tolerance to infectious diseases in animals. Science 2007;318:812-4.

[10] Read AF, Graham AL, Raberg L. Animal defenses against infectious agents: Is damage control more important than pathogen control. PLoS Biol 2008;6:e1000004.

[11] Ayres JS, Schneider DS. A signaling protease required for melanization in drosophila affects resistance and tolerance of infections. PLoS Biol 2008;6:2764-73.

[12] Schneider DS, Ayres JS. Two ways to survive infection: What resistance and tolerance can teach us about treating infectious diseases. Nat Rev Immunol 2008;8:889-95.

[13] Curtis VA. Infection-avoidance behaviour in humans and other animals. Trends Immunol 2014;35:457-64.

[14] Kiesecker JM, Skelly DK, Beard KH, Preisser E. Behavioral reduction of infection risk. Proc Natl Acad Sci U S A 1999;96:9165-8.

[15] Opsomer G, Grohn YT, Hertl J, Coryn M, Deluyker H, de Kruif A. Risk factors for post partum ovarian dysfunction in high producing dairy cows in belgium: A field study. Theriogenology 2000;53:841-57.

[16] Zwald NR, Weigel KA, Chang YM, Welper RD, Clay JS. Genetic selection for health traits using producer-recorded data. I. Incidence rates, heritability estimates, and sire breeding values. J Dairy Sci 2004;87:4287-94.

[17] Gernand E, Rehbein P, von Borstel UU, Konig S. Incidences of and genetic parameters for mastitis, claw disorders, and common health traits recorded in dairy cattle contract herds. $\mathrm{J}$ Dairy Sci 2012;95:2144-56. 
[18] Zinicola M, Bicalho MLS, Santin T, Marques EC, Bisinotto RS, Bicalho RC. Effects of recombinant bovine interleukin- 8 treatment on health, metabolism, and lactation performance in holstein cattle ii: Postpartum uterine health, ketosis, and milk production. J Dairy Sci 2019;102:10316-28.

[19] Denis-Robichaud J, Dubuc J. Determination of optimal diagnostic criteria for purulent vaginal discharge and cytological endometritis in dairy cows. J Dairy Sci 2015;98:6848-55.

[20] Ribeiro ES, Gomes G, Greco LF, Cerri RLA, Vieira-Neto A, Monteiro PLJ, Jr., et al. Carryover effect of postpartum inflammatory diseases on developmental biology and fertility in lactating dairy cows. J Dairy Sci 2016;99:2201-20.

[21] Stojkov J, von Keyserlingk MA, Marchant-Forde JN, Weary DM. Assessment of visceral pain associated with metritis in dairy cows. J Dairy Sci 2015;98:5352-61.

[22] Fourichon C, Seegers H, Malher X. Effect of disease on reproduction in the dairy cow: A meta-analysis. Theriogenology 2000;53:1729-59.

[23] Haimerl P, Heuwieser W. Invited review: Antibiotic treatment of metritis in dairy cows: A systematic approach. J Dairy Sci 2014;97:6649-61.

[24] Rochford C, Sridhar D, Woods N, Saleh Z, Hartenstein L, Ahlawat H, et al. Global governance of antimicrobial resistance. The Lancet 2018;391:1976-8.

[25] Lima FS, Vieira-Neto A, Snodgrass JA, De Vries A, Santos JEP. Economic comparison of systemic antimicrobial therapies for metritis in dairy cows. J Dairy Sci 2019;102:7345-58.

[26] Gier HT, Marion GB. Uterus of the cow after parturition: Involutional changes. Am J Vet Res 1968;29:83-96.

[27] Wagner WC, Hansel W. Reproductive physiology of the post partum cow. L. Clinical histological findings. J Reprod Fertil 1969;18:493-500.

[28] Beam SW, Butler WR. Energy balance and ovarian follicle development prior to the first ovulation postpartum in dairy cows receiving three levels of dietary fat. Biol Reprod 1997;56:133-42.

[29] Crowe MA. Resumption of ovarian cyclicity in post-partum beef and dairy cows. Reprod Domest Anim 2008;43 Suppl 5:20-8.

[30] Cheong SH, Sa Filho OG, Absalon-Medina VA, Pelton SH, Butler WR, Gilbert RO. Metabolic and endocrine differences between dairy dows that do or do not ovulate first postpartum dominant follicles. Biol Reprod 2016;94:18, 1-1.

[31] Drackley JK. Biology of dairy cows during the transition period: The final frontier? J Dairy Sci 1999;82:2259-73.

[32] Wathes DC, Cheng Z, Chowdhury W, Fenwick MA, Fitzpatrick R, Morris DG, et al. Negative energy balance alters global gene expression and immune responses in the uterus of postpartum dairy cows. Physiol Genomics 2009;39:1-13.

[33] Karstrup CC, Klitgaard K, Jensen TK, Agerholm JS, Pedersen HG. Presence of bacteria in the endometrium and placentomes of pregnant cows. Theriogenology 2017;99:43-7.

[34] Moore SG, Ericsson AC, Poock SE, Melendez P, Lucy MC. Hot topic: 16s rna gene sequencing reveals the microbiome of the virgin and pregnant bovine uterus. J Dairy Sci 2017;100:4953-60.

[35] Machado VS, Oikonomou G, Bicalho ML, Knauer WA, Gilbert R, Bicalho RC. Investigation of postpartum dairy cows' uterine microbial diversity using metagenomic pyrosequencing of the 16s rrna gene. Vet Microbiol 2012;159:460-9. 
[36] de Goffau MC, Lager S, Sovio U, Gaccioli F, Cook E, Peacock SJ, et al. Human placenta has no microbiome but can contain potential pathogens. Nature 2019;572:329-34.

[37] Sheldon IM, Noakes DE, Rycroft AN, Pfeiffer DU, Dobson H. Influence of uterine bacterial contamination after parturition on ovarian dominant follicle selection and follicle growth and function in cattle. Reproduction 2002;123:837-45.

[38] Peng Y, Wang Y, Hang S, Zhu W. Microbial diversity in uterus of healthy and metritic postpartum holstein dairy cows. Folia Microbiol (Praha) 2013;58:593-600.

[39] Wang M-L, Liu M-C, Xu J, An L-G, Wang J-F, Zhu Y-H. Uterine microbiota of dairy cows with clinical and subclinical endometritis. Front Microbiol 2018;9:2691.

[40] Jeon SJ, Vieira-Neto A, Gobikrushanth M, Daetz R, Mingoti RD, Parize ACB, et al. Uterine microbiota progression from calving until establishment of metritis in dairy cows. Appl Environ Microbiol 2015;81:6324-32.

[41] Knudsen LRV, Karstrup CC, Pedersen HG, Angen Ø, Agerholm JS, Rasmussen EL, et al. An investigation of the microbiota in uterine flush samples and endometrial biopsies from dairy cows during the first 7 weeks postpartum. Theriogenology 2016;86:642-50.

[42] Bicalho MLS, Lima S, Higgins CH, Machado VS, Lima FS, Bicalho RC. Genetic and functional analysis of the bovine uterine microbiota. Part ii: Purulent vaginal discharge versus healthy cows. J Dairy Sci 2017;100:3863-74.

[43] Jeon SJ, Cunha F, Ma X, Martinez N, Vieira-Neto A, Daetz R, et al. Uterine microbiota and immune parameters associated with fever in dairy cows with metritis. PLoS One 2016;11:e0165740.

[44] Sheldon IM, Rycroft AN, Dogan B, Craven M, Bromfield JJ, Chandler A, et al. Specific strains of escherichia coli are pathogenic for the endometrium of cattle and cause pelvic inflammatory disease in cattle and mice. PLOS ONE 2010;5:e9192.

[45] Bicalho RC, Machado VS, Bicalho ML, Gilbert RO, Teixeira AG, Caixeta LS, et al. Molecular and epidemiological characterization of bovine intrauterine escherichia coli. J Dairy Sci 2010;93:5818-30.

[46] Ernstberger M, Oehl H, Haessig M, Hartnack S, Bollwein H. Predicting the probability of conception in dairy cows with clinical endometritis based on a combination of anamnestic information and examination results. Theriogenology 2019;138:127-36.

[47] Bonnett BN, Martin SW, Gannon VP, Miller RB, Etherington WG. Endometrial biopsy in holstein-friesian dairy cows. Iii. Bacteriological analysis and correlations with histological findings. Can J Vet Res 1991;55:168-73.

[48] Westermann S, Drillich M, Kaufmann TB, Madoz LV, Heuwieser W. A clinical approach to determine false positive findings of clinical endometritis by vaginoscopy by the use of uterine bacteriology and cytology in dairy cows. Theriogenology 2010;74:1248-55.

[49] de Boer MW, LeBlanc SJ, Dubuc J, Meier S, Heuwieser W, Arlt S, et al. Invited review: Systematic review of diagnostic tests for reproductive-tract infection and inflammation in dairy cows. J Dairy Sci 2014;97:1-17.

[50] Wagener K, Gabler C, Drillich M. A review of the ongoing discussion about definition, diagnosis and pathomechanism of subclinical endometritis in dairy cows. Theriogenology 2017;94:21-30. 
[51] Benzaquen ME, Risco CA, Archbald LF, Melendez P, Thatcher MJ, Thatcher WW. Rectal temperature, calving-related factors, and the incidence of puerperal metritis in postpartum dairy cows. J Dairy Sci 2007;90:2804-14.

[52] LeBlanc SJ, Duffield TF, Leslie KE, Bateman KG, Keefe GP, Walton JS, et al. Defining and diagnosing postpartum clinical endometritis and its impact on reproductive performance in dairy cows. J Dairy Sci 2002;85:2223-36.

[53] Kumari S, Kumaresan A, Patbandha TK, Ravi SK. Risk factors for metritis and its effect on productive and reproductive performance in dairy cattle and buffaloes. Agricultural Research 2016;5:72-80.

[54] Bromfield JJ, Sheldon IM. Lipopolysaccharide initiates inflammation in bovine granulosa cells via the tlr4 pathway and perturbs oocyte meiotic progression in vitro. Endocrinology 2011;152:5029-40.

[55] Piersanti RL, Horlock AD, Block J, Santos JEP, Sheldon IM, Bromfield JJ. Persistent effects on bovine granulosa cell transcriptome after resolution of uterine disease. Reproduction 2019;158:35-46.

[56] McCarville JL, Ayres JS. Disease tolerance: Concept and mechanisms. Curr Opin Immunol 2017;50:88-93.

[57] Medzhitov R, Schneider DS, Soares MP. Disease tolerance as a defense strategy. Science 2012;335:936-41.

[58] Wang A, Luan HH, Medzhitov R. An evolutionary perspective on immunometabolism. Science 2019;363:eaar3932.

[59] Whistance LK, Arney DR, Sinclair LA, Phillips CJC. Defaecation behaviour of dairy cows housed in straw yards or cubicle systems. Applied Animal Behaviour Science 2007;105:14-25. [60] Thompson-Crispi KA, Hine B, Quinton M, Miglior F, Mallard BA. Short communication: Association of disease incidence and adaptive immune response in holstein dairy cows. J Dairy Sci 2012;95:3888-93.

[61] Curtis VA. A natural history of hygiene. Canadian Journal of Infectious Diseases and Medical Microbiology 2007;18.

[62] Newby NC, Duffield TF, Pearl DL, Leslie KE, LeBlanc SJ, von Keyserlingk MAG. Short communication: Use of a mechanical brush by holstein dairy cattle around parturition. J Dairy Sci 2013;96:2339-44.

[63] Val-Laillet D, Guesdon V, von Keyserlingk MAG, de Passillé AM, Rushen J. Allogrooming in cattle: Relationships between social preferences, feeding displacements and social dominance. Applied Animal Behaviour Science 2009;116:141-9.

[64] Proudfoot KL, Jensen MB, Weary DM, von Keyserlingk MAG. Dairy cows seek isolation at calving and when ill. J Dairy Sci 2014;97:2731-9.

[65] Zhang Y, Lu H, Bargmann CI. Pathogenic bacteria induce aversive olfactory learning in caenorhabditis elegans. Nature 2005;438:179-84.

[66] Boillat M, Challet L, Rossier D, Kan C, Carleton A, Rodriguez I. The vomeronasal system mediates sick conspecific avoidance. Curr Biol 2015;25:251-5.

[67] von Keyserlingk MAG, Weary DM. Maternal behavior in cattle. Horm Behav 2007;52:106-13.

[68] Hein M, Valore EV, Helmig RB, Uldbjerg N, Ganz T. Antimicrobial factors in the cervical mucus plug. Am J Obstet Gynecol 2002;187:137-44. 
[69] Zegels G, Van Raemdonck GAA, Coen EP, Tjalma WAA, Van Ostade XWM. Comprehensive proteomic analysis of human cervical-vaginal fluid using colposcopy samples. Proteome Science 2009;7:17.

[70] Adnane M, Meade KG, O'Farrelly C. Cervico-vaginal mucus (cvm) - an accessible source of immunologically informative biomolecules. Vet Res Commun 2018;42:255-63.

[71] Chapwanya A, Meade KG, Doherty ML, Callanan JJ, Mee JF, O'Farrelly C. Histopathological and molecular evaluation of holstein-friesian cows postpartum: Toward an improved understanding of uterine innate immunity. Theriogenology 2009;71:1396-407.

[72] Sheldon IM, Noakes DE, Rycroft A, Dobson H. Acute phase protein response to postpartum uterine bacterial contamination in cattle. Vet Rec 2001;148:172-5.

[73] Soares MP, Teixeira L, Moita LF. Disease tolerance and immunity in host protection against infection. Nat Rev Immunol 2017;17:83-96.

[74] Piersanti RL, Zimpel R, Molinari PCC, Dickson MJ, Ma Z, Jeong KC, et al. A model of clinical endometritis in holstein heifers using pathogenic escherichia coli and trueperella pyogenes. J Dairy Sci 2019;102:2686-97.

[75] Amos MR, Healey GD, Goldstone RJ, Mahan S, Duvel A, Schuberth HJ, et al. Differential endometrial cell sensitivity to a cholesterol-dependent cytolysin links trueperella pyogenes to uterine disease in cattle Biol Reprod 2014;90:54,1-13.

[76] Preta G, Lotti V, Cronin JG, Sheldon IM. Protective role of the dynamin inhibitor dynasore against the cholesterol-dependent cytolysin of trueperella pyogenes. FASEB J 2015;29:151628.

[77] Griffin S, Preta G, Sheldon IM. Inhibiting mevalonate pathway enzymes increases stromal cell resilience to a cholesterol-dependent cytolysin. Sci Rep 2017;7:17050.

[78] Griffin S, Healey GD, Sheldon IM. Isoprenoids increase bovine endometrial stromal cell tolerance to the cholesterol-dependent cytolysin from trueperella pyogenes. Biol Reprod 2018;99:749-60.

[79] Gonzalez MR, Bischofberger M, Freche B, Ho S, Parton RG, van der Goot FG. Poreforming toxins induce multiple cellular responses promoting survival. Cell Microbiol 2011;13:1026-43.

[80] Takeuchi O, Akira S. Pattern recognition receptors and inflammation. Cell 2010;140:80520.

[81] Turner ML, Cronin JC, Healey GD, Sheldon IM. Epithelial and stromal cells of bovine endometrium have roles in innate immunity and initiate inflammatory responses to bacterial lipopeptides in vitro via toll-like receptors tlr2, tlr1 and tlr6. Endocrinology 2014;155:145365.

[82] Cronin JG, Turner ML, Goetze L, Bryant CE, Sheldon IM. Toll-like receptor 4 and myd88-dependent signaling mechanisms of the innate immune system are essential for the response to lipopolysaccharide by epithelial and stromal cells of the bovine endometrium. Biol Reprod 2012;86:51, 1-9.

[83] Moresco EM, LaVine D, Beutler B. Toll-like receptors. Curr Biol 2011;21:R488-93.

[84] Healy LL, Cronin JG, Sheldon IM. Endometrial cells sense and react to tissue damage during infection of the bovine endometrium via interleukin 1. Sci Rep 2014;4:7060, 1-9. 
[85] Cronin JG, Kanamarlapudi V, Thornton CA, Sheldon IM. Signal transducer and activator of transcription-3 licenses toll-like receptor 4-dependent interleukin (il)-6 and il-8 production via il-6 receptor-positive feedback in endometrial cells. Mucosal Immunol 2016;9:1125-36.

[86] Chen GY, Nunez G. Sterile inflammation: Sensing and reacting to damage. Nat Rev Immunol 2010;10:826-37.

[87] Davies D, Meade KG, Herath S, Eckersall PD, Gonzalez D, White JO, et al. Toll-like receptor and antimicrobial peptide expression in the bovine endometrium. Reprod Biol Endocrinol 2008;6:53.

[88] Machado VS, Bicalho ML, Meira Junior EB, Rossi R, Ribeiro BL, Lima S, et al. Subcutaneous immunization with inactivated bacterial components and purified protein of escherichia coli, fusobacterium necrophorum and trueperella pyogenes prevents puerperal metritis in holstein dairy cows. PLoS ONE 2014;9:e91734.

[89] Joosten I, Sanders MF, Hensen EJ. Involvement of major histocompatibility complex class i compatibility between dam and calf in the aetiology of bovine retained placenta. Anim Genet 1991;22:455-63.

[90] Huzzey JM, Veira DM, Weary DM, von Keyserlingk MA. Prepartum behavior and dry matter intake identify dairy cows at risk for metritis. J Dairy Sci 2007;90:3220-33.

[91] Hammon DS, Evjen IM, Dhiman TR, Goff JP, Walters JL. Neutrophil function and energy status in holstein cows with uterine health disorders. Vet Immunol Immunopathol 2006;113:21-9.

[92] Turner ML, Cronin JG, Noleto PG, Sheldon IM. Glucose availability and amp-activated protein kinase link energy metabolism and innate immunity in the bovine endometrium. PLoS ONE 2016;11:e0151416.

[93] Noleto PG, Saut JP, Sheldon IM. Short communication: Glutamine modulates inflammatory responses to lipopolysaccharide in ex vivo bovine endometrium. J Dairy Sci 2017;100:2207-12.

[94] Lochmiller RL, Deerenberg C. Trade-offs in evolutionary immunology: Just what is the cost of immunity? Oikos 2000;88:87-98.

[95] O'Neill LA, Kishton RJ, Rathmell J. A guide to immunometabolism for immunologists. Nat Rev Immunol 2016;16:553-65.

[96] Kvidera SK, Horst EA, Abuajamieh M, Mayorga EJ, Fernandez MV, Baumgard LH. Glucose requirements of an activated immune system in lactating holstein cows. J Dairy Sci 2017;100:2360-74.

[97] Moret Y, Schmid-Hempel P. Survival for immunity: The price of immune system activation for bumblebee workers. Science 2000;290:1166-8.

[98] Niozas G, Tsousis G, Steinhöfel I, Brozos C, Römer A, Wiedemann S, et al. Extended lactation in high-yielding dairy cows. I. Effects on reproductive measurements. J Dairy Sci 2019;102:799-810.

[99] Markusfeld O. Factors responsible for post parturient metritis in dairy cattle. Vet Rec 1984;114:539-42.

[100] Dubuc J, Duffield TF, Leslie KE, Walton JS, LeBlanc SJ. Risk factors for postpartum uterine diseases in dairy cows. J Dairy Sci 2010;93:5764-71.

[101] Potter T, Guitian J, Fishwick J, Gordon PJ, Sheldon IM. Risk factors for clinical endometritis in postpartum dairy cattle. Theriogenology 2010;74:127-34. 
[102] Mulligan FJ, O'Grady L, Rice DA, Doherty ML. A herd health approach to dairy cow nutrition and production diseases of the transition cow. Anim Reprod Sci 2006;96:331-53. [103] Dobson H, Smith RF. What is stress, and how does it affect reproduction? Anim Reprod Sci 2001;60-61:743-52.

[104] Lewis GS. Steroidal regulation of uterine immune defenses. Anim Reprod Sci 2004;8283:281-94.

[105] Li SH, Huang HL, Chen YH. Ovarian steroid-regulated synthesis and secretion of complement $\mathrm{c} 3$ and factor $\mathrm{b}$ in mouse endometrium during the natural estrous cycle and pregnancy period. Biol Reprod 2002;66:322-32.

[106] Saut JP, Healey GD, Borges AM, Sheldon IM. Ovarian steroids do not impact bovine endometrial cytokine/chemokine responses to e. Coli or lps in vitro. Reproduction 2014;148:593-606.

[107] Britt JH, Cushman RA, Dechow CD, Dobson H, Humblot P, Hutjens MF, et al. Invited review: Learning from the future-a vision for dairy farms and cows in 2067. J Dairy Sci 2018;101:3722-41.

[108] Konig S, May K. Invited review: Phenotyping strategies and quantitative-genetic background of resistance, tolerance and resilience associated traits in dairy cattle. Animal 2019;13:897-908. 